\title{
GROWTH AND SURVIVAL OF ROHU, LABEO ROHITA (HAMILTON, 1822) SPAWN FED DIETS FERMENTED WITH INTESTINAL BACTERIUM, BACILLUS CIRCULANS
}

\author{
Koushik GHOSH${ }^{1}$, Sukanta Kumar $S E N^{2}$, Arun Kumar $R A Y^{1^{*}}$ \\ ${ }^{1}$ Fisheries Laboratory, Department of Zoology, and ${ }^{2}$ Microbiology Laboratory, \\ Department of Botany, Visva-Bharati University, Santiniketan, West Bengal, India
}

Ghosh K., Sen S.K., Ray A.K., 2004. Growth and survival of rohu, Labeo rohita (Hamilton) spawn fed diets fermented with intestinal bacterium, Bacillus circulans. Acta Ichthyol. Piscat. 34 (2): 155-165.

Background. Because of the advancement of multiple spawning of carps, the importance of a quality larval diet is increasing day by day. The larval fish do not have the necessary enzyme or the amount of digestive enzymes to digest feed at optimum level. Therefore, fermentation of feed ingredients and/or formulated diets by bacterial enzymes to produce simpler forms of nutrients may be beneficial for them.

Materials and methods. Five isocaloric ( $\left.4.38 \mathrm{kcal} \cdot \mathrm{g}^{-1}\right)$ and isonitrogenous (35\% crude protein approximately) experimental diets (D1-D5) containing 32\% fish meal, 34\% mustard oil cake, $30 \%$ rice bran, and $2 \%$ cod liver oil, were fermented in vitro with Bacillus circulans cells (at the rate of $10^{8}$ bacterial cells per $\mathrm{g}$ ) at $37^{\circ} \mathrm{C}$ for $1-5$ day duration ( 1 day: D1, 2 days: D2, 3days: D3, 4 days: D4, and 5 days: D5). The bacterial strain [extracellular enzyme producer Bacillus circulans ( $\operatorname{Lr} 1.1$ )] used for fermentation was isolated from the intestine of rohu, Labeo rohita fingerlings. The reference diet (RD), containing same ingredients, was not fermented with bacterial cells. Rohu spawn (av. wt. $0.35 \pm 0.01 \mathrm{mg}$ ) were fed ad libitum for 21 days in the laboratory condition at 30 minutes interval starting from $0900 \mathrm{~h}$ to $1600 \mathrm{~h}$.

Results. Fermentation of diets resulted in an increase in crude protein and free amino acid contents and decrease in crude fibre content. Diets D4 and D5 resulted in best growth and survival (98\% and $98.33 \%$, respectively) of rohu spawn compared to those fed with the reference diet (RD) and other experimental groups. A significant positive correlation was obtained between RNA : DNA ratio and specific growth rate (SGR) of 18 dietary groups (6 groups in triplicate).

Conclusion. Fermentation of feed ingredients may be practiced as a tool for starter diet formulation to obtain better growth and survival of rohu spawn. The enzymeproducing strain, Bacillus circulans could be used to ferment diets for 4 to 5 days to increase the bioavailability of nutrients.

Key words: fish, intestinal microflora; fermentation; diets; growth; survival; Labeo rohita spawn.

${ }^{*}$ Correspondence: Prof. Dr Arun Kumar Ray, Fisheries Laboratory, Department of Zoology, Visva-Bharati University, Santiniketan-731 235 , West Bengal, India, Phone/Fax: +91-3463-261268, e-mail: arun_rayl@ rediffmail.com 


\section{INTRODUCTION}

Considering the importance of survival and well being of carp larvae (spawn) in the fish culture programme, research on the nutrition of fish larvae/spawns should be prioritised. Due to non-availability of proper larval diet, the rate of survival in general, is very low. Therefore, supplemental nutrition in the form of artificial compound feed in appropriate quality and quantity is one of the important factors for better survival and growth of fish larvae. The importance of a quality larval diet is increasing day by day with the advancement of multiple spawning of carps. Several attempts have been made to develop artificial diets to replace live food in the rearing of fish post larvae (Chow 1980, Bryant and Matty 1981, Dabrowski and Kaushik 1985, Csengeri and Petitjean 1987, Alami-Durante et al. 1991, Mohanty et al. 1996, Ghosh et al. 2002a). Although there are reports on the use of microencapsulated diets (Chow 1980, Anonymous 1983), no standard larval diets are available for Indian major carps.

The intestinal tract of fish larvae is much more simple in organisation and shorter than that of the adults (Stroband and Dabrowski 1981), correlating with a low production of digestive enzymes. The larvae therefore, simply do not have the necessary enzymes or the amount of digestive enzymes to digest the feed at the optimal level. Hence, fermentation of feed ingredients by bacterial enzymes to produce simpler forms of nutrients may be beneficial for them. In an earlier study, we supplemented the diets for rohu, Labeo rohita (Hamilton, 1822) spawns with the enzyme-producing bacterial strain of Bacillus circulans (isolated from the intestine of healthy rohu fingerlings) and observed better survival and growth with bacteriasupplemented diets (Ghosh et al. 2002a). Moreover, there are chances of decrease in the activity of enzymes during processing of feeds. Keeping this view in mind, we fermented the diets with the same bacterial strain for different duration and evaluated the effect of fermented diets on growth and survival of rohu spawn. RNA : DNA ratio was measured after rearing period as an index of growth.

\section{MATERIALS AND METHODS}

Isolation and selection of gut bacterial flora

The bacterial strain was isolated from the intestine of ten healthy fingerlings of rohu, Labeo rohita (average weight $3.51 \pm 0.31 \mathrm{~g}$ ). The fish were starved for $24 \mathrm{~h}$ and the ventral surface of the fish was scrubbed with $1 \%$ iodine solution prior to dissection (Trust and Sparrow 1974). The intestine from all fish was dissected out aseptically and homogenized with $0.89 \% \mathrm{NaCl}$ solution (10:1) (Das and Tripathi 1991). The homogenate was used as inoculum. $1 \mathrm{ml}$ of homogenized sample $\left(10^{-1}\right)$ was spread on sterilized soybean-casein digest agar (Tryptone Soya Agar, Hi Media, Mumbai, India) plates and incubated at $37^{\circ} \mathrm{C}$ for $24 \mathrm{~h}$ in duplicate. Colonies with different morphological appearance were isolated and streaked separately on TSA plates to check their purity. Isolated colonies were characterized and identified (Ghosh et al. 
2002b). Among them Lr 1.1 strain of Bacillus circulans was selected for fermentation of diets because of its excellent protease and moderate cellulase producing capacities. Preparation of bacterial seed culture

The selected bacterial strain was grown in shake bottles in $4 \%$ tryptone soya broth (Hi-Media, India) for seed culture. After $24 \mathrm{~h}$ of growth at $37^{\circ} \mathrm{C}$, an average viable count of the suspension culture was about $10^{7}$ cells per ml of broth. This was used as bacterial seed for fermentation.

Diet preparation

The inclusive reference diet (RD), six isocaloric $\left(4.38 \mathrm{kcal} \cdot \mathrm{g}^{-1}\right)$ and isonitrogenous (35\% crude protein approximately) diets were prepared with the ingredient composition depicted in Table 1 (fish meal, 32\%; mustard oil cake, 34\%; rice bran, 30\%; cod liver oil, $2 \%$; and vitamin premix, 2\%). Experimental diets (D1 to D5) were fermented in vitro with $B$. circulans culture for different duration, viz. D1 for one day, D2 for two days, D3 for three days, D4 for four days, and D5 for five days, respectively. The reference diet (RD) was not fermented with bacterial culture. The feed ingredients were finely powdered and fortified with cod liver oil and vitamin mineral premix (Vitaminetes Forte, Roche India Ltd., Mumbai, India). The experimental diets were moistened with 50\% weight/volume liquid basal medium containing $\left[\mathrm{g} \cdot \mathrm{l}^{-1}\right.$ ]: $\mathrm{KH}_{2} \mathrm{PO}_{4}, 4 ; \mathrm{Na}_{2} \mathrm{HPO}_{4}, 4$; $\mathrm{MgSO}_{4} \cdot 7 \mathrm{H}_{2} \mathrm{O}, 0.2 ; \mathrm{CaCl}_{2}, 0.001 ; \mathrm{FeSO}_{4} \cdot 7 \mathrm{H}_{2} \mathrm{O}, 0.004$ and autoclaved for sterilization.

The sterilized diets were fermented with tryptone soya broth suspension culture of Bacillus circulans $\operatorname{Lr} 1.1$ at the rate of $10^{8}$ bacterial cells per $g$ for varying periods mentioned earlier at $37^{\circ} \mathrm{C}$ in an incubator. Following fermentation, the experimental diets were sun dried for 4 hours daily for 4 days. The dried diets were powdered and sieved to obtain micropellets prior to feeding (Table 2).

Experimental design

The experiment was conducted under laboratory conditions for 21 days. Rohu spawns were obtained from induced spawning of a single brood supplied by a local fish seed dealer. Four-day-old spawns were brought to the laboratory and acclimated for two days, feeding on mixed plankton. One hundred acclimated spawn of similar size (average length $5 \mathrm{~mm}$; weight $0.35 \mathrm{mg}$ ) were randomly distributed in plastic containers containing 151 non-chlorinated water from a deep tube well. Constant aeration was provided to each container using air compressor. Dissolved oxygen content, temperature, and $\mathrm{pH}$ of water amounted to $5.2-7.8 \mathrm{mg} \cdot 1^{-1}, 26.8-30.2^{\circ} \mathrm{C}$, and 6.5-7.5, respectively during the experimental period.

Feeds were offered ad libitum every 30 minutes commencing at $0900 \mathrm{~h}$ till $1600 \mathrm{~h}$ daily for 21 days. The unconsumed feed and faecal matter were removed twice a day by siphoning. The containers were thoroughly cleaned every alternate day and filled with fresh water.

Chemical analyses and data collection

Proximate composition of the diets was analysed according to the AOAC procedures (Anonymous 1990) as follows: Moisture was determined by oven drying 


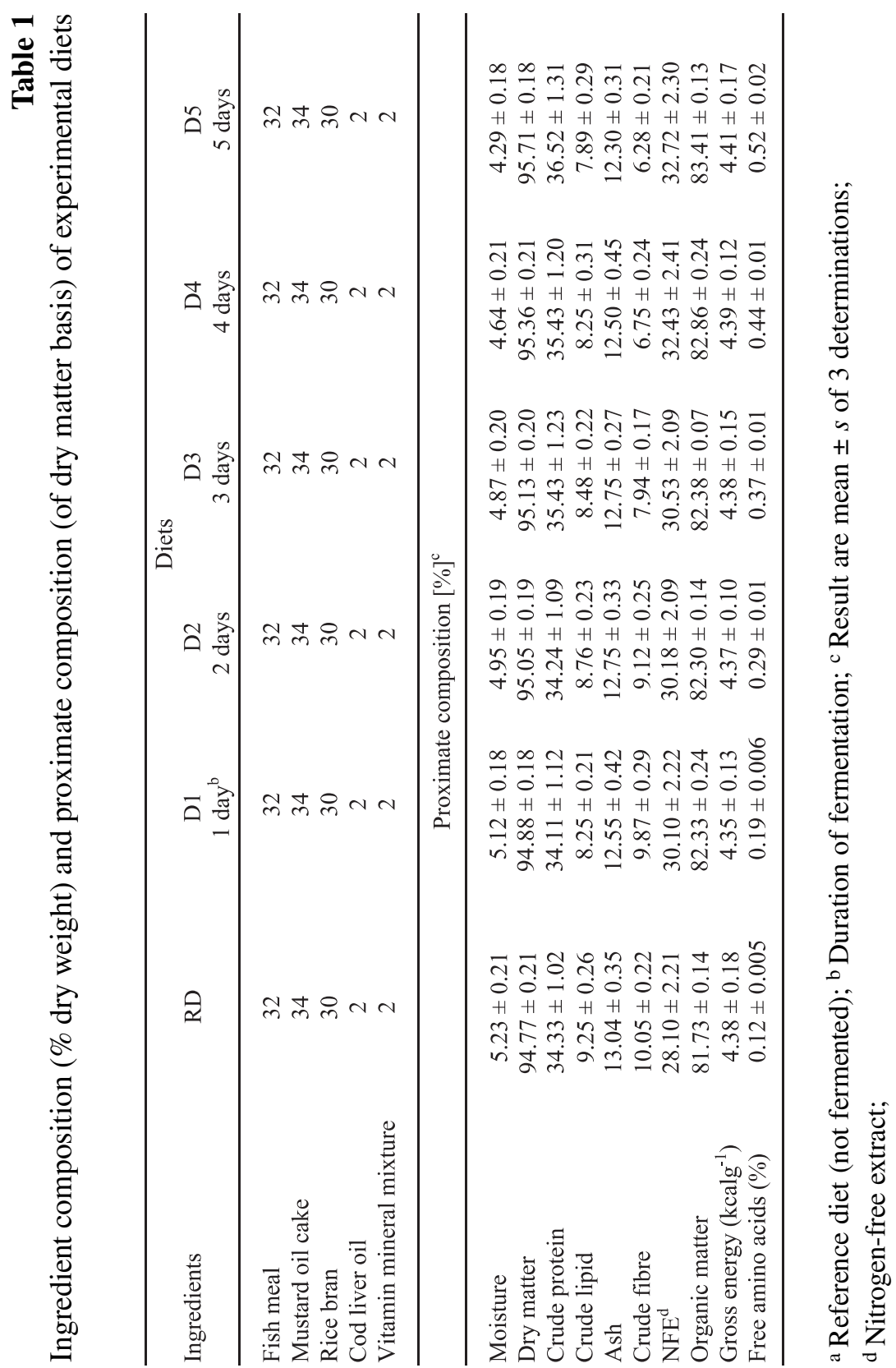


$\frac{0}{0}$

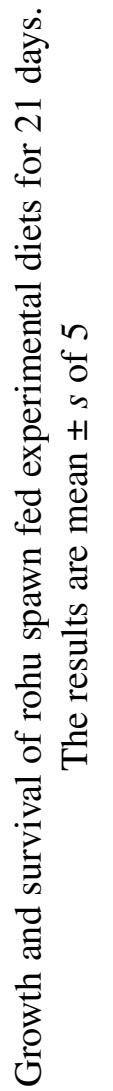

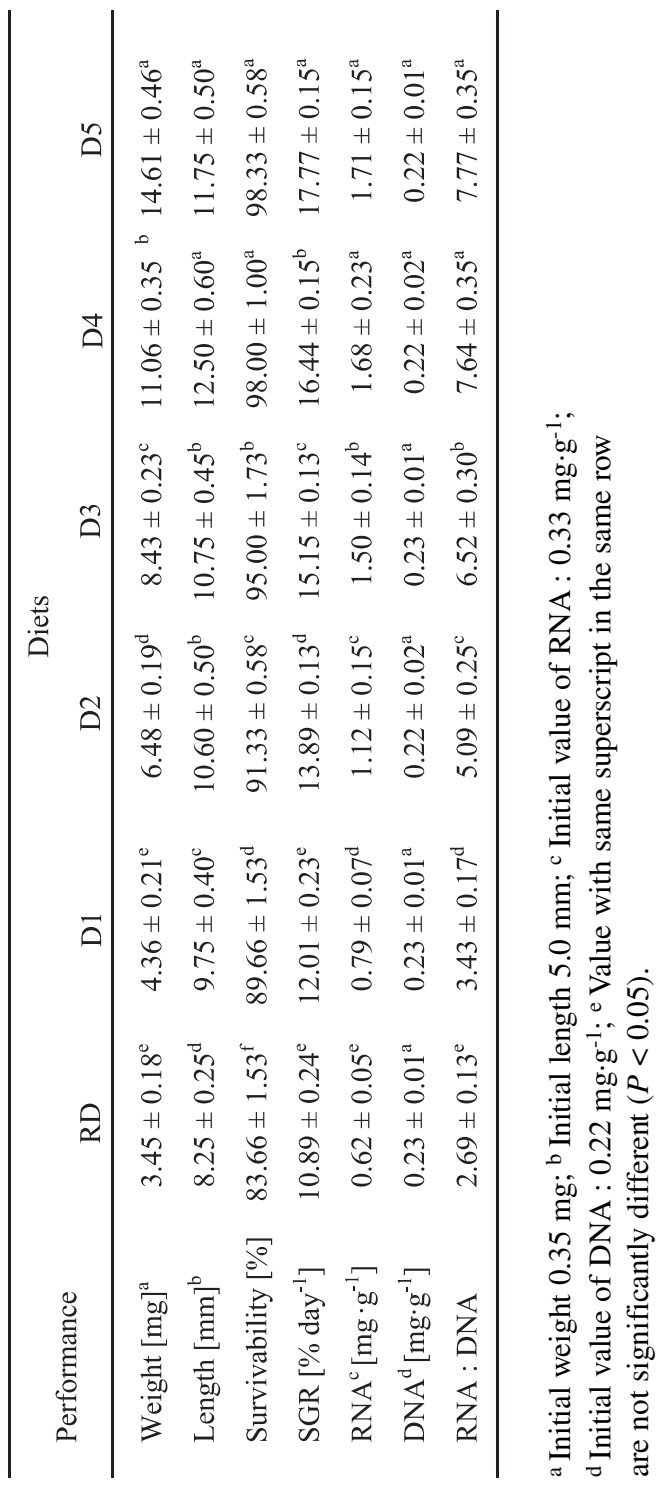


at $105^{\circ} \mathrm{C}$ for $24 \mathrm{~h}$; crude protein (nitrogen $\times 6.25$ ) by micro Kjeldahl digestion and distillation after acid digestion using a Kjeltec 1026 distilling unit together with a Tecator 2000 Digestion System (Tecator, Sweden); lipid by extracting the residue with $40-60^{\circ} \mathrm{C}$ petroleum ether for 7-8 $\mathrm{h}$ in a Soxhlet apparatus; crude fibre as loss on combustion of dried lipid-free residues after digestion with $1.25 \% \mathrm{H}_{2} \mathrm{SO}_{4}$ and $1.25 \%$ $\mathrm{NaOH}$; and ash was determined by combustion at $550^{\circ} \mathrm{C}$ in a muffle furnace to constant weight. Estimation of total free amino acids was conducted according to Moore and Stein (1948) using ninhydrin reagent dissolved in methyl cellosolve (2 methoxyethanol). Growth increment was monitored regularly at 5-day intervals by sampling 20 spawn from each container. Final sampling was done after 21 days by weighing all the surviving fish from each container after ensuring complete evacuation of feed by the starving process.

Average live weight gain [\%] and specific growth rate SGR [\% per day] were calculated using standard methods outlined by Steffens (1989).

To estimate DNA and RNA contents, DNA and RNA aliquots were prepared from $100 \mathrm{mg}$ of fish tissue (Munro and Fleck 1966). DNA and RNA contents of the aliquot were estimated following the methods of Burton (1956) and Marham (1955), respectively. The ratio of RNA to DNA was used as an index of growth.

The water quality parameters were monitored following the methods outlined by APHA (Anonymous 1985).

ANOVA, followed by multiple range test (Duncan 1955), was employed for statistical analysis. To correlate RNA : DNA ratio and specific growth rate, correlation coefficient ( $r$ value) and regression analysis between these two parameters were performed using Microsoft Excel software.

\section{RESULTS}

\section{Diets}

The ingredient composition and proximate composition of the formulated diets are presented in the Table 1. Diets were isonitrogenous (approximately 35\% crude protein) and isocaloric $\left(4.38 \pm 0.03 \mathrm{kcal} \cdot \mathrm{g}^{-1}\right)$. Dry matter and ash contents varied within a close range (95.71-94.77\% and $13.04-12.30 \%$, respectively). However, a decreasing trend of lipid content was noticed in the fermented diets. Fermentation of diets also decreased the crude fibre levels significantly, whereas, increase in the levels of crude protein and free amino acid contents was noticed.

Growth and survival

The performance of spawns in terms of growth, survival and RNA : DNA contents is depicted in Table 2. Fermented diets were acceptable to the spawns and no disease or abnormality was observed during the experimental period. Bacillus circulansfermented diet D5 resulted significantly $(P>0.05)$ higher growth and specific growth rate (SGR, \%) followed by diets D4 and D3. Survival of rohu spawn was also higher in the group fed diet D5 as compared to that with the reference diet (RD) and other 
experimental groups. Higher growth was supported by the increment of both, weight and length of the spawn. Poor survivability of spawn was recorded with the reference diet (without fermentation).

RNA : DNA ratio

The RNA and DNA contents of rohu spawn differed significantly $(P<0.05)$ among different dietary treatments. The group of spawn showing higher growth rate (with diet D5) exhibited higher RNA : DNA ratio. The elevated RNA : DNA ratio was associated with higher levels of RNA and lower levels of DNA.

A significant positive correlation was noticed between RNA : DNA ratio and specific growth rate of 18 dietary groups (6 groups in triplicate). The $r$-value (correlation coefficient) of 0.984 suggests a good direct relationship (99\% significant) between growth and the RNA : DNA ratio (Fig. 1).

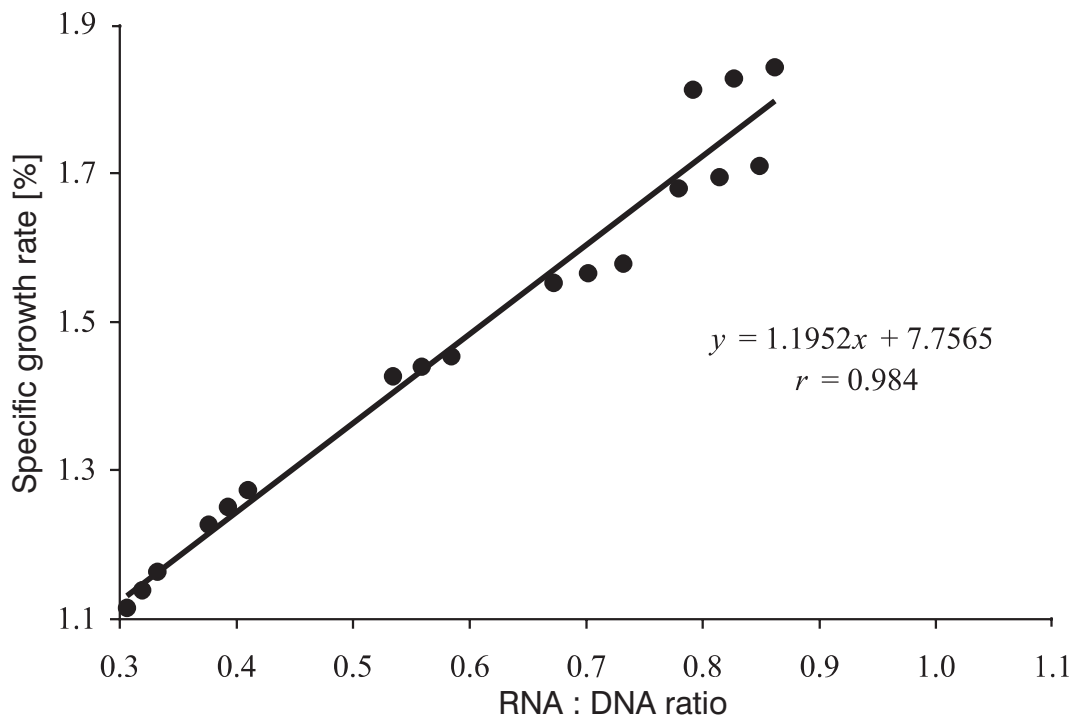

Fig. 1. A regression of the specific growth rate vs. RNA : DNA ratio of rohu spawn fed experimental diets for 21 days

The regression analysis in which specific growth rate was correlated to RNA : DNA ratio gave the regression line showing a slope of 1.195. The slope of the regression line was significant at the $10 \%$ level.

\section{DISCUSSION}

The development of fish farming on a commercial scale is limited for many species due to difficulties in producing sufficient quantities of larvae and juveniles, and high mortalities can occur during the early stages of larval rearing, especially during the transition from the yolk sac to the first feeding stage of development (Ring $\varnothing$ and Birkbeck 1999). 
It is well known that in nurseries, the rate of larval survival is very low (30-40\%) and hence use of the larval diet for large scale indoor rearing may be found economical in the long run without involving much management practices. In the present experiment, an attempt has been made to formulate a proper diet for rohu, Labeo rohita, spawn, where diets were fermented with an extracellular enzyme producing microflora in vitro for varying periods.

The differences recorded in growth and survival of rohu spawn between treatments could be attributed to the quality of diets. Fermentation of diets increased the nutritional efficiency of the formulated diet in rohu spawns. Fish fed diets D5 and D4 exhibited better growth and survival of spawns in comparison to the reference diet (without fermentation) and other experimental diets. Improvement of the nutritional efficiency of diet may be due to the fermentative effect of the bacteria used. The beneficial effects of probiotics in larval fish have been demonstrated by several investigators (Charlon and Bergot 1984, Dabrowski and Kaushik 1985, Bergot et al. 1986, Alami-Durante et al. 1991, Ghosh et al. 2002a). However, the effect of fermentation with a probiotic bacterium has not been demonstrated.

As indicated earlier, fish larvae do not have the necessary enzymes or the amount of digestive enzymes to digest the feed at the optimal level. In our previous study (Ghosh et al. 2002a), extracellular-enzyme-producing bacteria, Bacillus circulans promoted better growth and survival of rohu spawn that might be due to production of digestive enzymes and certain essential nutrients as indicated by Douillet and Langdon (1994), who observed faster growth and higher survival in Pacific oyster fed algae supplemented with CA2 bacterium. In this study, diets were fermented with the same extracellular enzyme producer strain Lr 1.1 of Bacillus circulans.

Nutrient losses may occur during fermentation as a result of leaching, destruction by light, heat or oxygen or microbial utilization (Jones 1975). However, loss of nutrients during fermentation is commonly negligible and there may be an increase in the nutrient level through microbial synthesis (Wee 1991). Bairagi et al. (2002) recommended the use of fermented Lemna leaf meal up to $30 \%$ as a dietary ingredient for Labeo rohita fingerlings without any adverse effect on growth. High levels of fibre in the diet are known to retard the growth of fish (Anonymous 1977, Edwards et al. 1985) and may be responsible for poor digestibility (De Silva et al. 1990). The fermentation of diets in the present study resulted in an increase in total free amino acids, and decrease in crude fibre level. Increase in total free amino acid content might be due to the bacterial breakdown of dietary protein, or production of amino acids (Fong and Mann 1980) by the extracellular protease producing bacteria during the process of fermentation. The bacterium, Bacillus circulans was found to produce moderate amount of cellulase (Ghosh et al. 2002b) and that might be the cause of decrease in crude fibre content of the diets. The beneficial effect of fermentation could be substantiated from the results of the present study as fish reared on fermented diets D5 and D4 showed better growth and higher survival (over 98\%) compared to other experimental diets. 
RNA and DNA contents in the spawn were measured both prior to commencement and on termination of the experiment, and the RNA : DNA ratio was correlated with growth. The usefulness of RNA concentration as an indicator of growth has been established by Neidhardt and Megasanik (1960) for bacteria and shown to be equally applicable to fish. Rapidly growing organisms apparently synthesize and accumulate the RNA needed for protein synthesis. Consequently, RNA and the ratio of RNA to DNA are useful as an index of growth. In the present study, RNA : DNA ratios in rohu spawn were positively correlated to the trends in growth as has been indicated by several workers (Bulow 1970, 1971, Haines 1973, 1980, Bulow et al. 1981, Ghosh et al. 2002a). Wilder and Stanley (1983) confirmed the relationship between growth and RNA : DNA ratios in brook trout, Salvelinus fontinalis and Atlantic salmon, Salmo salar. In the present study, the elevated RNA : DNA ratios were associated with higher levels of RNA and lower levels of DNA. Increased RNA : DNA ratios noticed in rohu spawn corresponding to growth increment are indicative of higher protein synthesis which could be attributed to fermented diets containing more total free amino acids than the reference diet.

\section{CONCLUSIONS}

Fermented diets could be recommended for rohu spawns in the nurseries for better survival and growth and that the enzyme producing fish intestinal bacterial strain of Bacillus circulans could be a suitable inoculum for fermentation. Fermentation for 4 to 5 days is sufficient to increase the bioavailability of nutrients to spawn.

\section{ACKNOWLEDGEMENTS}

The authors are grateful to the Indian Council of Agricultural Research, New Delhi [Project F. No. 4(28)/96-ASR-I] and the University Grants Commission (Department of Special Assistance Programme) for financial support.

\section{REFERENCES}

Alami-Durante H., Charlon N., Escaffre A.M., Bergot P., 1991. Supplementation of artificial diets for common carp (Cyprinus carpio L.) larvae. Aquaculture 93: 167-175.

Anonymous, 1977. Nutrient requirements of warm water fishes. National Research CouncilNational Academy of Sciences, Washington, DC.

Anonymous, 1983. Formulated feeds for aquaculture in the tropics. Fish feeds and feeding in developing countries-An interim report on the ADCP Feed Development Programme. Aquaculture Development and Coordination Programme. ADCP/REP/83/18 UNDP/FAO.

Anonymous, 1985. Standard methods for the examination of water and waste water. 16th edition. American Public Health Association, American Water Works Association and Water Pollution Control Federation, Washington, DC.

Anonymous, 1990. Official methods of analysis. 15th edition. Association of Official Analytical Chemists (AOAC), Washington, DC. 
Bairagi A., Sarkar Ghosh K., Sen S.K., Ray A.K., 2002. Duckweed (Lemna polyrhiza) leaf meal as a source of feedstuff in formulated diets for rohu (Labeo rohita Ham.) fingerlings after fermentation with a fish intestinal bacterium. Bioresource Technology 85: 17-24.

Bergot P., Charlon N., Durante H., 1986. The effect of compound diets feeding on growth and survival of coregonid larvae. Archiv für Hydrobiologie Beiheft. Ergebnisse der Limnologie 22: 265-272.

Bryant P.L., Matty A.J., 1981. Adaptation of carp (Cyprinus carpio) larvae to artificial diets. 1. Optimum feeding rate and adaptation age for a commercial diet. Aquaculture 23: 275-286.

Bulow F.J., 1970. RNA-DNA ratios as indicators of recent growth rates of a fish. Journal of Fisheries Research Board of Canada 27: 2343-2349.

Bulow F.J., 1971. Selection of suitable tissues for use in the RNA-DNA ratio technique of assessing recent growth rate of a fish. Iowa State Journal of Science 46: 71-78.

Bulow F.J., Zeman M.E., Winningham J.R., Hudson W.F., 1981. Seasonal variations in RNADNA ratios and in indicators of feeding, reproduction, energy storage and condition in a population of bluegill, Lepomis macrochirus, Rafinesque. Journal of Fish Biology 18: 237-244.

Burton K., 1956. A study condition mechanisms of diphenyl amine reaction for the estimation of DNA. Journal of Biochemistry 62: 315.

Charlon N., Bergot P., 1984. Rearing system for feeding fish larvae on dry diets. Trial with carp (Cyprinus carpio L.) larvae. Aquaculture 41: 1-9.

Chow K.W., 1980. Microencapsulated egg diets for fish larvae. pp. 355-361. In: Fish Feed Technology. Aquaculture Development and Coordination Programme. ADCP/REP/80/11, UNDP/FAO, Rome.

Cox H.E., Pearson D., 1962. The chemical analysis of foods. Chemical Publishing Co. Inc., New York.

Csengeri I., Petitjean M., 1987. Fresh liver powder: a new starter diet for the larvae of a cyprinid fish. Aquaculture 65: 189-192.

Dabrowski K.R., Kaushik S.J., 1985. Rearing of coregonid (Coreconus schinzi pallea Cuv. et Val.) larvae using dry and live food. III. Growth of fish and developmental characteristics related to nutrition. Aquaculture 48: 123-135.

Das K.M., Tripathi S.D., 1991. Studies on the digestive enzymes of grass carp, Ctenopharyngodon idella (Val.). Aquaculture 92: 21-32.

Douillet A., Langdon J., 1994. Use of a probiotic for the culture of larvae of the Pacific oyster (Crassostrea cicas Thunberg). Aquaculture 119: 25-40.

Duncan D.B., 1955. Multiple range and multiple $F$-tests. Biometrics 11: 1-42.

Edwards P., Kamal M., Wee K.L., 1985. Incorporation of composted and dried water hyacinth in pelleted feed for the tilapia Oreochromis niloticus (Peters). Aquaculture and Fisheries Management 1: 233-248.

Fong W., Mann K.H., 1980. Role of gut flora in the transfer of amino acids through a marine food chain. Canadian Journal of Fisheries and Aquatic Science 37: 88-96.

Ghosh K., Sen S.K., Ray A.K., 2002a. Growth and survival of rohu, Labeo rohita (Hamilton) spawn fed diets supplemented with fish intestinal microflora. Acta Ichthyologica et Piscatoria 32(1) : 83-92.

Ghosh K., Sen S.K. Ray A.K., 2002b. Characterization of bacilli isolated from gut of rohu, Labeo rohita, fingerlings and its significance in digestion. Journal of Applied Aquaculture 12(3) : 33-42. 
Haines T.A., 1973. An evaluation of RNA-DNA ratio as a measure of long-term growth in fish populations. Journal of Fisheries Research Board of Canada 30: 195-199.

Haines T.A., 1980. Seasonal patterns of muscle RNA-DNA ratio and growth in black crappie, Pomoxis nigromaculatus. Environmental Biology of Fishes 5: 67-70.

Jones I.D., 1975. Effect of processing by fermentation of nutrients. p. 324. In: Harris R.S., Karmas E., (eds.) Nutritional Evaluation of Food Processing. AVI Publishers, Westport, Connecticut.

Marham R., 1955. Nucleic acids, their components and related compounds. In: Paech K., Tracey M.V., (eds.) Modern Methods of Plant Analysis. Vol.4. Springer-Verlag, Berlin.

Mohanty S.N., Swain S.K., Tripathi S.D., 1996. Rearing of catla (Catla catla Ham.) spawn on formulated diets. Journal of Aquaculture in the Tropics 11: 253-258.

Moore S., Stein W.H., 1948. Photometric ninhydrin method for use in the chromatography of amino acids. Journal of Biological Chemistry 176: 367-388.

Munro H.N., Fleck A., 1966. Recent developments in the measurement of nucleic acids in biological materials. Analyst 91: 78-88.

Neidhardt F.C., Magasanik B., 1960. Studies on the role of ribonucleic acid in the growth of bacteria. Biochimica et Biophysica Acta 42: 99-116.

Ringø E., Birkbeck T.H., 1999. Intestinal microflora of fish larvae and fry. Aquaculture Research 30: 73-93.

De Silva S.S., Shim K.F., Ong A.K., 1990. An evaluation of the method used in digestibility estimations of a dietary ingredient and comparisons on external and internal markers and time of faeces collection in digestibility studies in the fish Oreochromis aureus (Stendachner). Reproduction, Nutrition, Development 30: 215-226.

Steffens S.H., 1989. Principles of Fish Nutrition. Ellis Horwood, Chichester.

Stroband H.W.J., Dabrowski K., 1981. Morphological and physiological aspects of the digestive system and feeding in freshwater fish larvae. pp. 355-378. In: Fontaine M., (ed.) Nutrition des Poissons. CNRS, Paris.

Trust T.J., Sparrow R.A.H., 1974. The bacterial flora in the alimentary tract of freshwater salmonid fishes. Canadian Journal of Microbiology 20: 1219-1228.

Wilder I.B., Stanley J.G., 1983. RNA-DNA ratio as an index to growth in salmonid fishes in the laboratory and in streams contaminated by carbaryl. Journal of Fish Biology 22: 165-172.

Wee K.L., 1991. Use of non-conventional feedstuff of plant origin as fish feeds-Is it practical and economically feasible? pp. 13-32. In: De Silva S.S., (ed.) Fish Nutrition Research in Asia. Asian Fisheries Society Special Publication, Vol. 5. Proceedings of the Fourth Asian Fish Nutrition Workshop. Asian Fisheries Society, Manila, Philippines.

Received: 12 March 2004 Accepted: 18 November 2004 